\title{
Cloning and Characterization of Glycolate Oxidase and NADH-Dependent Hydropyruvate Reductase Genes in \\ Pachysandra terminalis
}

\author{
Suping Zhou, ${ }^{1}$ Fur-Chi Chen, Samuel Nahashon, and Tingting Chen \\ Institute of Agricultural and Environmental Research, Tennessee State \\ University, 3500 John A. Merritt Blvd., Nashville, TN 37209
}

Additional index words. cold stress, real-time qRT-PCR, Rubisco activase

\begin{abstract}
Photorespiration provides a protection mechanism in plants by diverting excessive energy accumulated from photochemical reaction, metabolizing toxic products and producing some protective molecules. The authors report cloning and characterization of a glycolate oxidase gene (GOX; NCBI accession DQ442286) and a NADHdependent hydroxypyruvate reductase gene (HPR; NCBI DQ442287) from Pachysandra terminallis. The DQ442286 had the predicted GOX-like-Riboflavin-5' -phosphate (FMN) conserved domain and the DQ442287 had the predicted adenosine 5 '-(alpha-thio)diphospho-5' -ribofuranosylnicotinamide nicotinamide adenine dinucleotide (NAD) binding domain (2-Hacid_DH_C). C-terminal peroxisome targeting signal was predicted to be -ARL for DQ442286 and -SKL for DQ442287. Both genes encoded enzyme proteins that are located in peroxisome and are involved in the photorespiration process. Realtime quantitative reverse-transcriptase polymerase chain reaction was performed to compare transcript level of the cloned genes after cold treatment. The 18s Ribosomal RNA (rRNA) was included to calibrate the data. The relative cycle threshold values (gene/18s rRNA) were 1.4, 1.5, and 1.5 for GOX and 1.2, 1.3, and 1.3 for HPR in the treatments of $4{ }^{\circ} \mathrm{C} 4 \mathrm{~h}, 4{ }^{\circ} \mathrm{C} 12 \mathrm{~h}$, and control. The data revealed that gene expression was enhanced by only short-term (4-h) cold treatment. A ribulose-1, 5-biphosphate carboxylase/oxygenase (Rubisco) activase gene (DQ 486905) was also cloned and analyzed following the same procedure.
\end{abstract}

Chilling $\left(5-10{ }^{\circ} \mathrm{C}\right)$ is one of the major abiotic stresses periodically experienced by different species of crops and native plants growing in temperate regions (Tsonev et al., 2003). Low temperature can enhance $\mathrm{O}_{2}$ uptake processes (Flexas et al., 1999) as oxygen solubility increases from 4 to 5 $\mathrm{mg} / \mathrm{L}$ at $50{ }^{\circ} \mathrm{C}$ to 10 to $11 \mathrm{mg} / \mathrm{L}$ at $10{ }^{\circ} \mathrm{C}$ and 13 to $14 \mathrm{mg} / \mathrm{L}$ at $0{ }^{\circ} \mathrm{C}$ (www.omega.com/ techref/ph-1.html). A high concentration of $\mathrm{O}_{2}$ in the cellular spaces will activate or enhance photorespirations (Byrd and Brown, 1989). Although photorespiration results in the loss of as much as $25 \%$ of the carbon that is fixed during photosynthetic carbon assimilation (Ludwig and Canvin, 1971), it is considered to be an essential metabolic pathway (Somerville and Ogren, 1982; Wu et al., 1991). Inhibitors of photorespiration en-

\footnotetext{
Received for publication 15 Mar. 2006. Accepted for publication 10 Apr. 2006. This research was financially supported through a grant from the United State Department of Agriculture, Cooperative State Research, Education and Extension Service, project award no. 2002-38814-12598. Dr. Nick Gawel and Ms. Sarabjit M. Bhatti at Tennessee State University reviewed this paper.

${ }^{1}$ To whom reprint requests should be addressed; e-mail zsuping@tnstate.edu
}

Glycolate oxidase (GOX) and NADH-dependent hydropyruvate reductase (HPR) are two major enzymes located in peroxisomes involved in the photorespiration process (Fig. 1). These proteins are encoded in the nucleus and are synthesized in the cytoplasm on free ribosomes (de Hoop and Ab, 1992; Lazarow and Fujiki, 1985; Subramani, 1993). They are targeted to peroxisomes by a noncleaved C-terminal tripeptide of the prototype SKL, the peroxisome targeting signal type 1 (PTS1), or conservative variations thereof (Gould et al., 1987, 1989; Olsen et al., 1993; Reumann, 2004). The PTS as well as the pathway is conserved to a large extent throughout the eukaryotic kingdom (Frederich et al., 1973; Gould et al., 1990).

Different GOX genes have been isolated from different plant species that are cold tolerant, such as Arabidopsis (Arabidopsis thaliana) (Sato et al., 2000) and spinach (Spinacea oleracea) (Cederlund et al., 1988), and those that are cold sensitive, such as tomato (Lycopersicon esculentum) (Speirs et al., 1995) and pumpkins (Cucurbita sp.) (Tsugeki et al., 1993). The activity of GOX is affected by low-temperature stress. Its activity was estimated to be about onethird at $4{ }^{\circ} \mathrm{C}$ compared with that at $25{ }^{\circ} \mathrm{C}$ in the high-mountain plant species Ranunculus glacialis (Streb et al., 2005). Maintaining stable level of GOX activity is essential for protection from photoinhibition during irradiation in transgenic tobacco (Yamaguchi and Nishimura, 2000). The NADH-dependent HPR catalyzes the reaction for serine to be transaminated to hydroxypyruvate in the peroxisomes (Fig. 1). HPR gene expression is regulated by light, hormone, and $\mathrm{CO}_{2}$ concentrations as well as water status (Wingler et al., 1998). Rubisco activase is an adenosine triphosphate (ATP) hydrolyzing (ATPase) enzyme. It causes a conformational change in the ribulose-1, 5-biphosphate carboxylase/oxygenase ( $\mathrm{Ru}-$ bisco) from closed to open form, from inactive to active state. The activity of Rubisco activase is temperature dependent (Michael and Crafts-Brandner, 2004). Reducing the activity of Rubisco activase can cause reduction in photosynthesis (Salvucci et al., 2001).

Pachysandra terminalis is an evergreen plant species. It grows best at 20 to $24^{\circ} \mathrm{C}$ and can survive growing zone 5 in the United States, where the low temperature can drop to -10 to $-20{ }^{\circ} \mathrm{C}$. Chilling $\left(0-10{ }^{\circ} \mathrm{C}\right)$ is one of the major environmental stresses facing the nursery industry. It is also a process when over-winter plants acclimatize and prepare to survive subzero freezing temperatures. Understanding the molecular mechanism involved in this process is very important for breeding and selection of cold-tolerant genotypes. We report cloning and characterization of GOX and NADHdependent HPR as well as the Rubisco activase genes from the cold-hardy $P$. terminalis plants. Regulation of gene expression under cold treatments was compared through real-time quantitative reverse-transcriptase polymerase chain reaction (qRTPCR). Results from this research may 


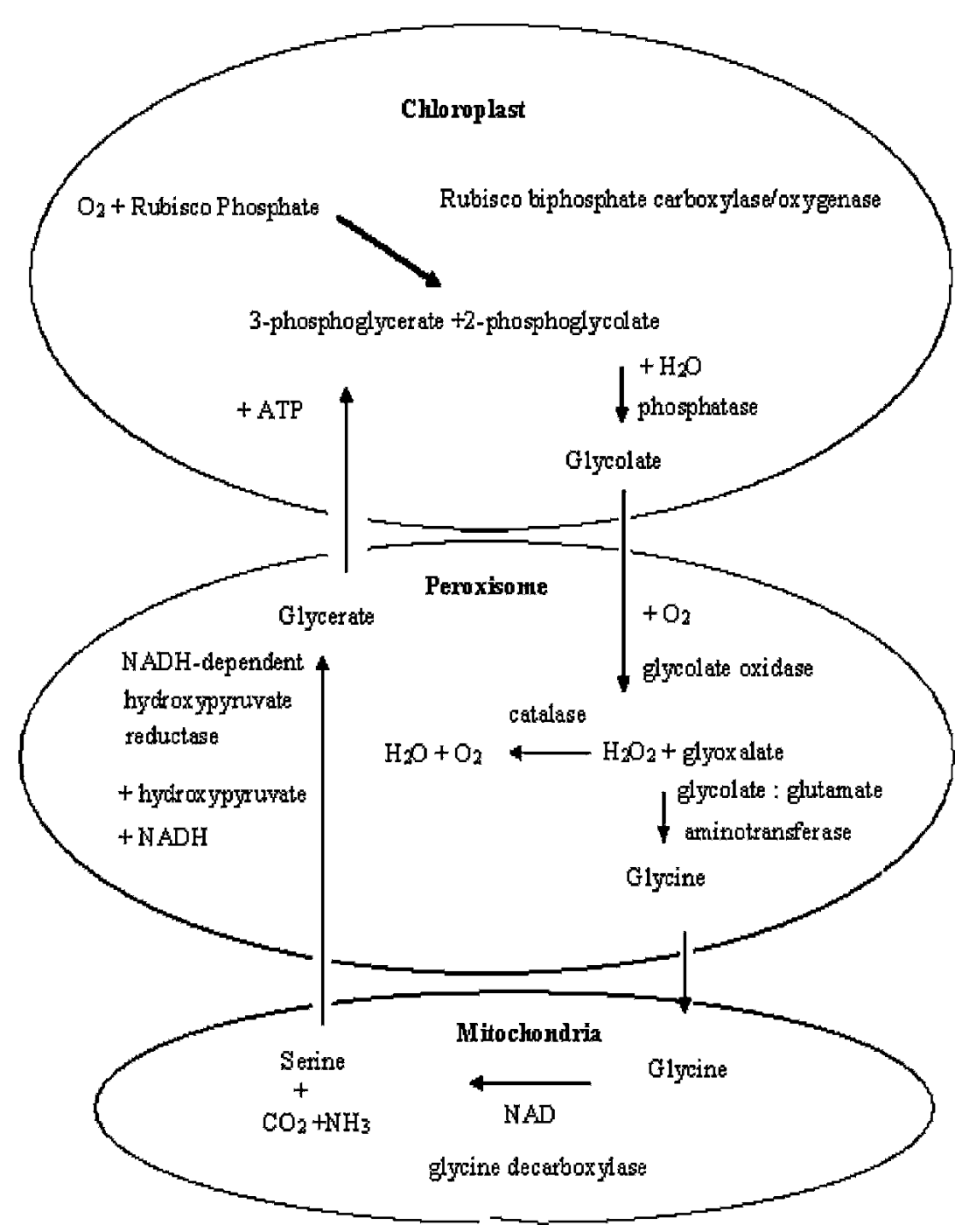

Fig. 1. Diagram of photorespiration process.

contribute to the understanding of the mechanism involved in the adaptation of evergreen plants to cold stress.

\section{Materials and Methods}

\section{Plant Material Preparation}

$P$. terminalis cuttings were purchased from Yoder Brothers, Inc. (www.yoder.com/). These cutting were growing in a greenhouse for 2 weeks, when new leaves grew out into full size. These new leaves were collected and used for total RNA extraction. Before cold treatments, these plants were incubated in a growth chamber at a photon flux density of $100 \mu \mathrm{mol} \mathrm{m}{ }^{-2} \mathrm{~s}^{-1}$ and a 24-hour photoperiod under a constant temperature of 24 to $25^{\circ} \mathrm{C}$ for $5 \mathrm{~d}$. Plants were then transferred to a temperature regime of $4{ }^{\circ} \mathrm{C}$ with the same light conditions. Leaf tissues were sampled at $5 \mathrm{~h}$ and $12 \mathrm{~h}$ of treatment. Leaves collected after 5 $\mathrm{d}$ of incubation at $25{ }^{\circ} \mathrm{C}$ were considered controls. Collected leaf tissues were frozen in liquid $\mathrm{N}_{2}$ and stored at $-80{ }^{\circ} \mathrm{C}$.

\section{Total RNA Isolation}

Total RNA was extracted using RNA pure kit (Genhunter, Nashville, Tenn.) following titer of the library in recombinant plaqueforming units was $7.1 \times 10^{6}$. After amplification, the cDNA libraries were lifted onto $\mathrm{N}^{+}$nylon membrane (Promega, Madison, Wis.) and hybridized with the probes prepared from gene fragments previously identified (Zhou et al., 2005). The conditions for membrane hybridization were prehybridization at $42{ }^{\circ} \mathrm{C}$ overnight, hybridization at $42{ }^{\circ} \mathrm{C}$ overnight, followed by two 20-min washes in $1 \times$ SSC buffer (Sambrook et al., 1989) $(7.5 \mathrm{mM} \mathrm{NaCl}$, $0.75 \mathrm{mM} \mathrm{Na}_{3}$ citrate; $\mathrm{pH}, 7.0$ ) and in $0.25 \times$ SSC and $0.1 \%$ sodium dodecyl sulphate (SDS) at $50{ }^{\circ} \mathrm{C}$. The prehybridization and hybridization buffers contained $50 \%$ formamide and $0.1 \%$ SDS, $5 \times$ Denhardt (Sigma, St. Louis, Mo.), $5 \times$ SSPE (0.75 M sodium chloride, 50 $\mathrm{mM}$ sodium hydrogen phosphate, $5 \mathrm{mM}$ ethylenediamine tetraacetic acid (EDTA); $\mathrm{pH}, 7.4)$ and $100 \mathrm{mg} \cdot \mathrm{L}$ herring sperm DNA (Sigma). After hybridization, signals were detected on radiographic film by overnight exposure at $70^{\circ} \mathrm{C}$. The positive clones were cured from the original NYZ plates and the cDNA library clones were used to subclone inserts by singleclone excision for conversion of $\lambda$ phage to pBlueScript SK-phagemid vector. The resulting phagemid libraries were plated at low density on Luria Bertani agar plates containing ampicillin $100 \mathrm{mg} \cdot \mathrm{L}$. Single-strand cDNA was rescued from the phagemid and sequenced from both ends using M13 primers.

\section{Real-time qRT-PCR}

Real-time qRT PCR assay was performed using two-step procedures following the instruction in the SYBR-Green PCR Mix/RT kit (Applied Biosystems, FosterCity, Calif.). Genomic DNA was removed from total RNA with DNaseI (Genhunter). The DNA-free RNA was then quantified with a spectrophotometer and was loaded on a denaturing agarose gel to control concentration and integrity. Five micrograms of the RNA was reverse transcribed into cDNA using the MultiScribe Reverse Transcriptase (Applied Biosystems) according to the manufacturer's instructions.

To perform the PCR amplification, genespecific oligonucleotide primers were designed using OligoPerfect ${ }^{\mathrm{TM}}$ Designer (Invitrogen, Carlsbad, Calif.; www.invitrogen. com/). 18S rRNA forward and reverse primers were designed based on the sequence of Genebank accession NC-003071. The position of these oligonucleotides had been chosen so that the size of the PCR product ranged between $50 \mathrm{bp}$ and $150 \mathrm{bp}$. The genes, the sequence of their specific oligonucleotide primers, and other information are presented in Table 1. The cDNA was amplified on a 7000 Real Time PCR System (Applied Biosystems) using a program of 40 cycles of $94{ }^{\circ} \mathrm{C}, 30$ seconds, and $60^{\circ} \mathrm{C}, 1$ minute.

Real-time PCR results were detected as cycle threshold $(\mathrm{Ct})$. $\mathrm{Ct}$ is the cycle at which a significant increase in amount of PCR product (measured by increase in fluorescence) occurs, generally the middle of the exponential phase of amplification. The higher $\mathrm{Ct}$ value means there is less cDNA 
Table 1. Real-time PCR primers of glycolate oxidase, NADH-dependent hydropyruvate reductase and Rubisco activase genes in Pachysandra terminalis.

\begin{tabular}{|c|c|c|c|c|}
\hline Genes & Accession no. & Plant species & Primers forward/reverse & Amplicon, bp \\
\hline 18S rRNA & NC-003071 & Arabidopsis thaliana & $\begin{array}{l}5^{\prime} \text {-CATCAGCTCGCGTTGACTAC-3' } \\
5^{\prime} \text {-CACTTCACCGGATCATTCAA-3' }\end{array}$ & 110 \\
\hline GOX & DQ442286 & $\begin{array}{c}\text { Pachysandra } \\
\text { terminalis }\end{array}$ & $5^{\prime}$-TCCAAATGCTTCACGATGAG & 100 \\
\hline HPR & DQ442287 & P. terminalis & $\begin{array}{l}\text { 5'-GTGAGCGGCATCCACTTAAT } \\
5^{\prime} \text {-CCATTTGGTGCAAAATCAAA-3' } \\
5^{\prime} \text {-ACACTGTTGGCAGCTTTCCT }\end{array}$ & 80 \\
\hline $\mathrm{RA}^{\mathrm{z}}$ & 779769 & P. terminalis & $\begin{array}{l}\text { 5'-GTTCAGCTCCCCGGTATGTA-3' } \\
5^{\prime} \text {-CGGATAAGAGGGGCATACAA }\end{array}$ & 95 \\
\hline
\end{tabular}

${ }^{\mathrm{z}}$ Rubisco activase.

Table 2. Characteristics of selected cDNA clones from Pachysandra terminalis

\begin{tabular}{|c|c|c|c|c|}
\hline $\begin{array}{l}\text { Clones } \\
\text { accession no. }\end{array}$ & Conserved domain & $\begin{array}{l}\text { Groups (known } \\
\text { homolog) }\end{array}$ & $\begin{array}{l}\text { Identity (\%) of } \\
\text { deduced amino } \\
\text { acid }\end{array}$ & $\begin{array}{c}\text { Predicted } \\
\text { peroxisome } \\
\text { targeting } \\
\text { Signal }\end{array}$ \\
\hline DQ442286 GOX & GOX_like_FMN & Q9LRR9 (Arabidopsis) & 81 & $-\mathrm{ARL}$ \\
\hline Bankit779769 RA ${ }^{z}$ & $\mathrm{AAA}$ & P10896 (Arabidopsis) & 85 & $\mathrm{n} / \mathrm{a}$ \\
\hline $\begin{array}{l}\text { DQ442287 NADH- } \\
\text { dependent HPR }\end{array}$ & 2-Hacid_dh_C & BAA19751 (Arabidopsis) & & $-\mathrm{SKL}$ \\
\hline
\end{tabular}

${ }^{\mathrm{z}}$ Rubisco activase. sequence at the start of PCR. Because realtime PCR is a procedure of high sensitivity (Charrier et al., 2002), each real-time PCR was repeated twice to minimize the potential bias introduced by handling during the preprepeats were averaged and considered the $\mathrm{Ct}$ value for the PCR. To minimize the effect of variables in RNA extraction on the Ct value, the housekeeping gene 18S rRNA was used for RNA normalization. The relative $\mathrm{Ct}$ was used to measure the transcript level in each sample. It was calculated as

$$
\text { Relative } \mathrm{Ct}=\mathrm{A} \div \mathrm{B}
$$

where A is the average of real-time PCR replicates of each sample and $B$ is the average of two values of $18 \mathrm{~S}$ rRNA. Four repeats were included in each independent temperature treatment. The specificity of real-time PCR was validated by separation of the amplicons on $2 \%$ agarose gels.

\section{Sequence Analysis and Database Search}

DNA sequence analysis was performed on a 3100 Avant Genetic Analyzer (Applied Biosystems). The DNA sequences were translated into peptide using the ExPASy translation tool (www.expasy.ch/tools/ dna.html). Protein and DNA sequence data were searched against the database on the NCBI Web site (www.ncbi.nlm.nih.gov). PTS prediction was performed using the PTS1 predictor (http://mendel.imp.ac.at/ mendeljsp/sat/pts1/PTS1 predictor.jsp).

\section{Results and Discussion}

\section{Characterization of the cDNA Clones from $P$. terminalis}

The NCBI database was searched for DNA sequences that were homologous to those previously identified (Zhou et al., 2005). Three of the clones were identified aration process. The $\mathrm{Ct}$ values from the two bankit779769 had the predicted conserved domain of AAA (ATPases associated with a variety of cellular activities) (Neuwald et al., 1999), which designated it to be an ATPase enzyme. The amino acid sequence shared $85 \%$ identity with Arabidopsis Rubisco activase at the $\mathrm{C}$-terminal sequence. Based on these results, the bankit779769 was predicted as a putative Rubisco activase gene.

The deduced polypeptide of DQ442286 was predicted to have the conserved domain of GOX-like-FMN, which is the core sequence for GOX. The PST tripeptide at the C-terminal of DQ442286 was -ARL, which is conserved in Arabidopsis (Q9LRR9) and spinach (P05414). The deduced peptide sequence of DQ442287 had a conserved D-isomer specific 2-hydroxyacid dehydrogenase, NAD binding domain (2Hacid_DH_C). It had the tripeptide of SKL at the C-terminal. The prediction of the targeting signal peptide using the PTS1 predictor located this enzyme protein in the peroxisome (Neuberger et al., 2003). Based on its possible function, location, and homology $(88 \%)$ with other NADH-dependent HPR (BAA19751 from Arabidopsis), this gene was predicted to encode a putative NADH-dependent HPR (Table 2).

\section{Expression of the Gene Clones at Low Temperature in the Leaves of $P$. terminalis}

When the real-time PCR products were separated on $2 \%$ agarose gels, one specific band with the expected size (80-110 bp) was observed for each gene (Fig. 2). This result validated the specificity of the real-time PCR and the reliability of the $\mathrm{Ct}$ values.

qRT-PCR was performed to compare the number of the gene transcripts contained in the RNA extracts of each treatment to predict

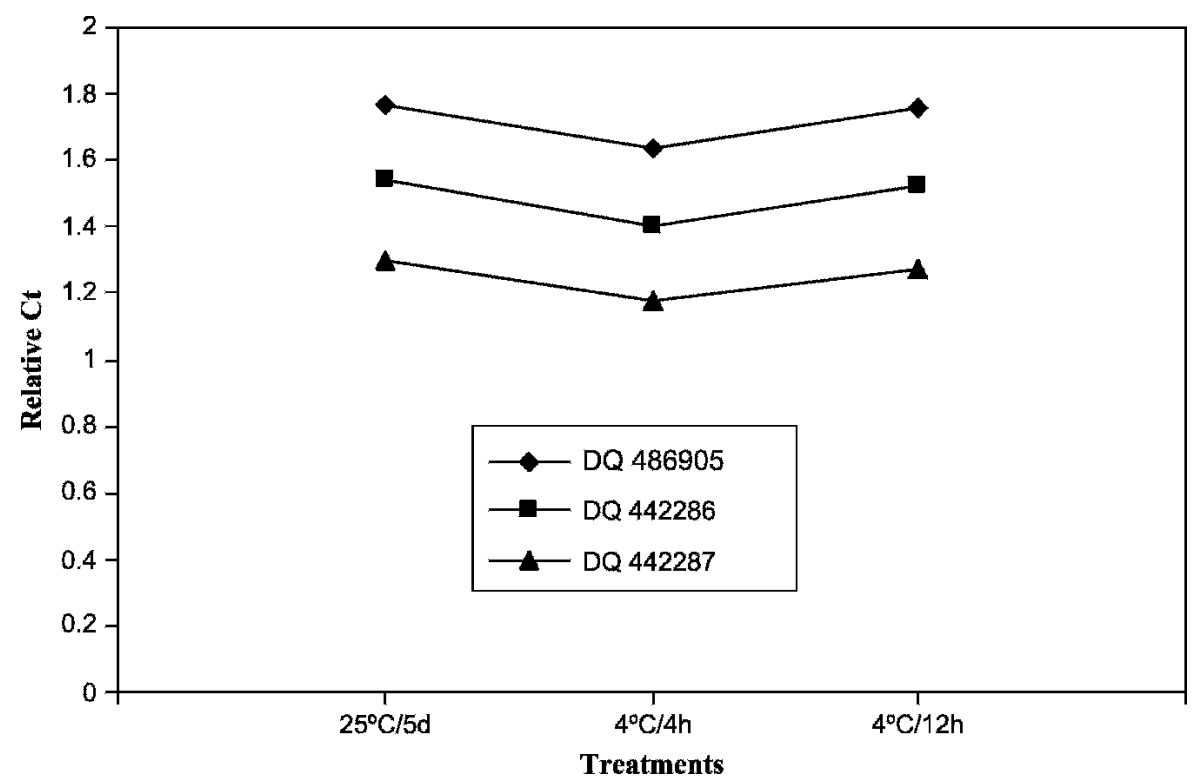

Fig. 2. Real-time PCR products of glycolate oxidase (GOX DQ442286), NADH-dependent hydropyruvate reductase (HPR DQ442287) and Rubisco activase genes (RA Bankit779769) in Pachysandra terminalis and housekeeping gene (18S rRNA) separated on $2 \%$ agarose gel. 
GOX DQ442286

HPR DQ442287

DQ 486905

$100 \mathrm{bp}$

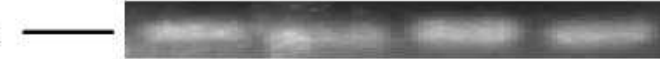

18S rRNA

$100 \mathrm{bp}$

$100 \mathrm{bp}$

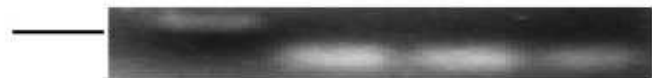

$100 \mathrm{bp}$

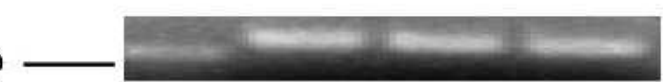

\section{DNA marker $\quad 25^{\circ} \mathrm{C} / 5 \mathrm{~d} \quad 4^{\circ} \mathrm{C} / 4 \mathrm{~h} \quad 4^{\circ} \mathrm{C} / 12 \mathrm{~h}$}

Fig. 3. Real-time qRT-PCR of glycolate oxidase, NADH-dependent hydropyruvate reductase, and Rubisco activase genes in Pachysandra terminalis. The relative $\mathrm{Ct}=\mathrm{A} \div \mathrm{B}$, where $\mathrm{A}$ is the average of two realtime PCR replicates of each RNA extraction and B is the average of two values of $18 \mathrm{~s}$ rRNA. Four replicates were included in each treatment.

transcription regulation of these genes by cold stress. The relative $\mathrm{Ct}$ values and changing patterns are presented in Figure 3. The standard deviation $(\mathrm{SD})$ values were between $8 \%$ and $11 \%$ of the average value (data not shown). Because the relative $\mathrm{Ct}$ value was calculated as the ratio of the absolute transcript level of each gene to the absolute transcript level of $18 \mathrm{~s}$ rRNA, the SDS are not displayed (Charrier et al., 2002). Figure 3 shows that for all three genes, the relative $\mathrm{Ct}$ values were the lowest in the $4{ }^{\circ} \mathrm{C}$ treatment for $4 \mathrm{~h}$. This indicated that more gene transcripts were accumulated in the leaf tissues with this treatment. Extending the cold treatment to $12 \mathrm{~h}$ resulted in an increase of the $\mathrm{Ct}$ values and a decrease of gene transcripts. One of the possible mechanisms is that short-term (4-h) chilling stress activated or enhanced the photorespiration process and thus upregulated expression of the GOX and HPR genes, and resulted in more gene transcripts accumulated in leaf tissues. When the cold stress lasted for a longer period of time (12 h), more enzyme molecules were needed because of the accumulation of substrates and the decrease of the enzyme activity at lower temperature (Rocha et al., 2003; Streb et al., 2005). The increased translation of messenger RNA into protein would consume some gene transcripts, leading to the decrease in the number of the transcripts and the increase of $\mathrm{Ct}$ values. Real-time qRT-PCR also showed that the Rubisco activase gene had the same expression pattern as the peroxisome genes in response to chilling stress in $P$. terminalis. Further study is needed for investigating the stress regulation of these genes at the protein and enzyme activity levels.

\section{Literature Cited}

Andrews, T.J., G.H. Lorimer, and N.E. Tolbert. 1971. Incorporation of molecular oxygen into glycine and serine during photorespiration in spinach leaves. Biochemistry 10:4777-4782.

Byrd, G.T. and R.H. Brown. 1989. Environmental effects on photorespiration of $\mathrm{C} 3-\mathrm{C} 4$ species. Plant Physiol. 90:1022-1028.
Cederlund, E.Y., X. Lindqvist, G. Soderlund, C.I. Branden, and H. Jornvall. 1988. Primary structure of glycolate oxidase from spinach. Eur. J. Biochem. 173:523-530.

Charrier, B., A. Champion, Y. Henry, and M. Kreis. 2002. Expression profiling of the whole Arabidopsis shaggy-like kinase multigene family by real-time reverse transcriptase-polymerase chain reaction. Plant Physiol. 130:577590.

Ellen, F.S., P.J. Gruber, and N.E. Tolbert. 1973. The occurrence of glycolate dehydrogenase and glycolate oxidase in green plants: an evolutionary survey 1 . Plant Physiol. 52:318323.

Erickson, L., B. Förster, R.T. Furbank, and W.S. Chow. 2004. Processes contributing to photoprotection of grapevine leaves illuminated at low temperature. Physiol. Plant 121:272281.

de Hoop, M.J. and G. Ab. 1992. Import of proteins into peroxisomes and other microbodies. Biochem. J. 286:657-669.

Flexas, J., J.M. Escalona, and H. Medrano. 1999 Water stress induces different levels of photosynthesis and electron transport rate regulations in grapevines. Plant Cell Environ. 22: $39-48$.

Frederich, S.E., P.J. Gruber, and N.E. Tolbert 1973. The occurrence of glycolate dehydrogenase and glycolate oxidase in green plants. An evolutionary survey. Plant Physiol. 52:318323.

Gould, S.G., G.A. Keller, and S. Subramani. 1987. Identification of a peroxisomal targeting signal at the carboxy terminus of firefly luciferase. J. Cell Biol. 105:2923-2931.

Gould, S.J., G.-A. Keller, N. Hosken, J. Wilkinson, and S. Subramani. 1989. A conserved tripeptide sorts proteins to peroxisomes. J. Cell Biol. 108:1657-1664.

Gould, S.J., G.-A. Keller, M. Schneider, S.H Howell, L.J. Garrard, J.M. Goodman, B. Distel, H. Tabak, and S. Subramani. 1990. Peroxisomal protein import is conserved between yeast, plants, insects and mammals. EMBO J. 9:85-90

Hendrickson, L., B. Förster, R.T. Furbank, and W.S. Chow. 2004. Processes contributing to photoprotection of grapevine leaves illuminated at low temperature. Physiol. Planta. 121:272-281.

Kisaki, T. and N.E. Tolbert. 1969. Glycolate and glyoxylate metabolism by isolated peroxi- somes or chloroplasts. Plant Physiol. 44:242250.

Kozaki, A. and G. Takeba. 1996. Photorespiration protects $\mathrm{C}_{3}$ plants from photooxidation. Nature 384:557-560.

Lazarow, P.B. and Y. Fujiki. 1985. Biogenesis of peroxisomes. Annu. Rev. Cell Biol. 1:489530.

Ludwig, J. and D.T. Canvin. 1971. The rate of photorespiration during photosynthesis and the relationship of the substrate of light respiration to the products of photosynthesis in sunflower leaves. Plant Physiol. 48:712-719.

Michael, E.S. and S.J. Crafts-Brandner. 2004. Relationship between the heat tolerance of photosynthesis and the thermal stability of Rubisco activase in plants from contrasting thermal environments. Plant Physiol. 134: 1460-1470.

Neuberger, G., S. Maurer-Stroh, B. Eisenhaber, A. Hartig, and F. Eisenhaber. 2003. Prediction of peroxisomal targeting signal 1 containing proteins from amino acid sequence. J. Mol. Biol. 328:581-592.

Neuwald, A.F., L. Aravind, J.L. Spouge, and E.V. Koonin. 1999. $\mathrm{AAA}^{+}$: A class of chaperonelike ATPases associated with assembly, operation, and disassembly of protein complexes. Genome Res. 9:27-43.

Ogren, W.L. 1984. Photorespiration: Pathways, regulation, and modification. Annu. Rev. Plant Physiol. 35:415-442.

Olsen, L.J., W.F. Ettinger, B. Damsz, K. Matsudaira, M.A. Webb, and J. Harada. 1993. Targeting of glyoxysomal proteins to peroxisomes in leaves and roots of a higher plant. Plant Cell 5:941-952.

Omega.com. Technical dissolved oxygen-The Fundamentals. http://www.omega.com/techref/ ph-1.html. Accessed 29 Mar. 2006.

Rocha, M.J., E. Rocha, A.D. Resende, and A.L. da Cunha. 2003. Measurement of peroxisomal enzyme activities in the liver of brown trout (Salmo trutta) using spectrophotometric methods. http://www.biomedcentral.com/14712091/4/2. Accessed 3 Oct. 2006.

Reumann, S. 2004. Specification of the peroxisome targeting signals type 1 and type 2 of plant peroxisomes by bioinformatics analyses. Plant Physiol. 135:783-800.

Salvucci, M.E., K.W. Osteryoung, S.J. CraftsBrandner, and E. Vierling. 2001. Exceptional sensitivity of Rubisco activase to thermal denaturation in vitro and in vivo. Plant Physiol. 127:1053-1064.

Sambrook, J., E.F. Fritsch, and T. Maniatis. 1989. Molecular Cloning: A Laboratory Manual. Ed 2. Cold Spring Harbor Laboratory, Cold Spring Harbor, N.Y.

Sato, S., Y. Nakamura, T. Kaneko, T. Katoh, E. Asamizu, and S. Tabata. 2000. Structural analysis of Arabidopsis thaliana chromosome 3. DNA Res. 7:131-135.

Somerville, C. and W.L. Ogren. 1982. Genetic modification of photorespiration. Trends Biochem. Sci. 7:171-174.

Speirs, J., R. Hinde, R. Paulin, and E. Lee. 1995. Nucleotide sequence of a cDNA encoding tomato glycolate oxidase (accession no. X92888) (PGR95-118). Plant Physiol. 110:336.

Streb, P., E.-M. Josse, E. Gallouet, F. Baptist, M. Kuntz, and G. Cornic. 2005. Evidence for alternative electron sinks to photosynthetic carbon assimilation in the high mountain plant species Ranunculus glacialis. Plant Cell Environ. 28:1123-1135. 
Subramani, S. 1993. Protein import into peroxisomes and biogenesis of the organelle. Annu. Rev. Cell Biol. 9:445-478.

Tolbert, N.E. 1971. Microbodies-peroxisomes and glycosomes. Annu. Rev. Plant Physiol. 22: 45-74.

Tolbert, N.E. 1981. Metabolic pathways in peroxisomes and glyoxysomes. Annu. Rev. Biochem. 50:133-157.

Tsonev, T., V. Velikova, K. Georgieva, P.F. Hyde, and H.G. Jones. 2003. Low temperature enhances photosynthetic down-regulation in French bean (Phaseolus vulgaris L.) plants. Ann. Bot. (Lond.) 91:343-352.

Tsugeki, R., I. Hara-Nishimura, H. Mori, and M. Nishimura. 1993. Cloning and sequencing of cDNA for glycolate oxidase from pumpkin cotyledons and Northern blot analysis. Plant Cell Physiol. 34:51-57.

Wingler, A., P.J. Lea, W.P. Quick, and R.C. Leegood. 2000. Photorespiration: Metabolic pathways and their role in stress protection. Phil. Trans. R. Soc. Lond. B 355:1517-1529.

Wingler, A., W.P. Quick, R.A. Bungard, K.J. Bailey, P.J. Lea, and R.C. Leagood. 1999. The role of photorespiration during drought stress: An analysis utilizing barley mutants with reduced activities of photorespiratory enzymes. Plant Cell Environ. 22:361-373.

Wingler, A., A. Von Schaewen, R.C. Leegood, P.J. Lea, and W.P. Quick. 1998. Regulation of leaf senescence by cytokinin, sugars, and light. Effect on NADH-dependent hydroxypyruvate reducatase. Plant Physiol. 116:329-335.
Wu, J., S. Neimanis, and U. Heber. 1991. Photorespiration is more effective than the Mehler reaction in protecting the photosynthetic apparatus against photoinhibition. Bot. Acta 104:283-291.

Yamaguchi, K. and M. Nishimura. 2000. Reduction to below threshold levels of glycolate oxidase activities in transgenic tobacco enhances photoinhibition during irradiation. Plant Cell Physiol. 41:13971406.

Zhou, S.P., R. Sauve, and A. Abudullah. 2005. Identification of genes regulated by low temperature in Pachysandra terminalis Sieb, et Zuuc using cDNA differential display. HortScience 40:1995-1997. 